\title{
ФОЛЬКЛОР И МИСТИКА В ПОВЕСТИ Н. В. ГОГОЛЯ «ВИЙ». ОТ АВТОРСКОГО ТЕКСТА К СОВРЕМЕННЫМ ЭКРАНИЗАЦИЯМ.
}

\author{
Галина Марешова, Татьяна Савченко
}

\section{FOLKLORE AND MYSTICISM IN GOGOL'S NOVEL VIJ. FROM THE AUTROR'S TEXT TO CONTEMPORARY FILM PROCESSING.}

\author{
Halyna Mareshova, Tatiana Savchenko
}

\begin{abstract}
Резюме: В данной статье рассматриваются фольклорные, мистические и юмористические мотивы повести Н. В. Гоголя «Вий», а также особенности изображения главных героев. В статье также сравнивается изображение Хомы Брута, ведьмы-панночки и Вия в повести «Вий» и выбранных экранизациях, а также обращается внимание на соотношение фольклора, мистики и юмора повести и фильмах.
\end{abstract}

Ключевые слова: Н. В. Гоголь, Вий, юмор, мистика, фольклор, экранизация

\begin{abstract}
This article discusses folklore, mysticism and humor in the novel Viy by N. V. Gogol. The article compares the novel and in the selected film adaptations, it draws attention to the depiction of the main characters, folklore, mysticism and humor.
\end{abstract}

Key words: N.V. Gogol, Viy, humor, mysticism, folklore, film adaptation

DOI: $10.14712 / 9788076032088.11$

\section{1 Введение}

В настоящее время экранизация литературных произведений оказывает влияние на формирование читательской моды: современный читатель, до известной степени становится, зрителем. Молодое поколение зачастую знакомится с произведениями классической и современной литературы именно благодаря кинематографии. Исследование данного феномена, с одной стороны, помогает понять вкусы и предпочтения современного зрителя, а, с другой, делает возможными превращение современного зрителя снова в читателя.

Повесть Н. В. Гоголя «Вий» была впервые опубликована в сборнике «Миргород» в 1835 году. Повесть стала предметом многих исследований и в разные периоды трактовалась поразному: в советской период акцент делался на социальной проблематике, а в постсоветский литературоведами отмечалась близость этой повести к народно-поэтическим традициям и мотивам.

В российском кинематографе фильмы по мотивам повести «Вий» были сняты шесть раз: в 1909 г., 1916 г., 1967 г., 2006 г., 2014 г. и в 2018 г. Экранизации 1909 г. и 1916 г. были утрачены. Фильм 1967 года был снят в СССР Кинокомпанией Мосфильм. Эта картина сохранилась до наших дней. В 2006 году был снят фильм под названием «Ведьма». Фильм существенно отличался от произведения Н. В. Гоголя: была сохранена лишь фабула повести. В 2014 году состоялась премьера четвертого фильма по мотивам повести Н. В. Гоголя «Вий», а в 2018 году - пятая. 
В данной статье представлены результаты исследования соотношения фольклорных элементов, мистики и юмора в экранизациях повести Н. В. Гоголя «Вий» в сравнении со сценами такого же плана в повести писателя. Для сравнения мы остановились на трёх фильмах: фильме «Вий» 1967 г. (режиссеры К. Ершов и Г. Кропачёв), фильме «Вий» 2014 г. (режиссер О. Степченко) и фильме «Гоголь. Вий» 2018 г. (режиссер Е. Баранов).

\section{2 Фольклорные мотивы повести «Вий»}

В повести «Вий» самыми яркими фольклорным мотивами являются мотивы, характерные для былички и волшебной сказки. «Быличка - фольклорный жанр - рассказ о якобы происшедшем в действительности чудесном событии - в основном о встрече с духами» (Тишков, Ситянский, онлайн). Для жанра былички характерна встреча героя с нечистой силой, и противостояние главного героя силам зла. При этом в быличке сюжет зачастую взят из повседневной жизни. Встреча героя с потусторонним миром всегда играет важную роль в судьбе главного героя (Туровец, онлайн). Так и в повести «Вий» встреча Хомы Брута с нечистой силой навсегда изменила его жизнь

В фольклоре силы зла имеют власть только в тёмное время суток, с наступлением же утра они ее теряют, а петушиный крик часто бывает предметом спасения героев от нечистой силы. Так и в повести «Вий» панночка с первыми лучами солнца и со вторым криком петуха возвращается обратно в гроб.

В повести «Вий» есть также мотивы, характерные для сказки. Например, главный герой вынужден преодолеть силы зла, читая молитвы над телом умершей ведьмы. В этой сцене мы видим, присущую многим сказочным сюжетам традицию, согласно которой герой должен преодолеть данное ему судьбой испытание именно три раза: Хома вынужден три ночи проводить молебен над мёртвой панночкой. В сказке каждое последующие испытание даётся герою всё сложнее, а последнее испытание является самым сложным. Так и Хома Брут в первую ночь, в церкви, увидел только летающий гроб и мёртвую ведьму, которая из всех сил старалась его поймать. На вторую ночь панночка уже "творила заклинания» и призвала на помощь «несметные силы», которые «бились крыльями о стёкла церкви, царапались визгом когтями о железные рамы» (Гоголь 1949, 177). После второй ночи Хома поседел. А в последнюю ночь ведьма позвала Вия, и Хома не выдержал испытания и погиб.

Также в повести отражено народное представление о том, что человек не должен встречаться с демонологическими персонажами взглядом. В народных поверьях такое действие для простого смертного всегда имеет роковые последствия. Так и Хома Брут, взглянув в глаза Вия, умер (Софронова 2010, 109).

Сказочным является также сюжет превращение избитой старухи в молодую панночку и мотив катания ведьмы верхом на человеке (Туровец, онлайн).

\section{3 Мистика в повести «Вий»}

В повести Н. В. Гоголя «Вий» фольклор и мистика тесно связаны между собой. Как писал В. А. Туровец: «Нечисть, появляющуюся в повести, можно отнести как к религиозномистическому, так и к фольклорному, однако, именно здесь (в повести Н. В. Гоголя "Вий») проявляется их тесная взаимосвязь.» (онлайн).

Герои повести «Вий», хуторяне, верили в мистические силы и в возможность коммуникации с ними. На хуторе существовало много рассказов о событиях "достоверно» случившихся, правдивость которых подтверждало много людей. Так, например, местный казак 
Дорош утверждал, что панночка была ведьмой и что однажды каталась по небу верхом на нём лично. Также местные мужчины соглашались с утверждением, что многие из «баб - ведьмы» ...и «когда старая баба, то и ведьма.» (Гоголь 1949, 169). В конце повести звонарь Халява, бывших семинарист, друг погибшего Хомы, уже со знанием дела утверждает: «Ведь у нас в Киеве все бабы, которые сидят на базаре, - все ведьмы.» (Гоголь 1949, 169).

В результате трудно сказать случаются ли мистические события в жизни героев от того, что они в них свято верят, или местные люди свято верят в мистические события потому, что они случаются на хуторе, и в какой мере рождению этих явлений способствует местная горилка. Но так или иначе, мистика является неотъемлемой частью повседневной жизни местных людей.

\section{4 Юмор в повести «Вий»}

Несмотря на невеселый конец, повесть Н. В. Гоголя «Вий» не производит на читателя мрачного впечатления. Уже при выборе имён героев Н. В. Гоголь использует приём контраста: соединяет необычные имена с вполне обычными фамилиями. Например, одного из героев повести зовут Тиберий Горобець (необычное имя скомбинировано со вполне обыденной фамилией), а еще один герой - богослов Халява (возвышенная профессия сочетается с обычной, даже несколько ироничной, фамилией) (Букарева 2009, 6).

А. Н. Букарева подчёркивала, что сюжет «Вия» насыщен реальными картинами, и именно в бытовых сценах чувствуется народный юмор, жизненная убедительность образов, и всё это создает общий эмоциональный тон повествования $(2009,60)$. Уже на первых страницах повести описание учеников монастыря проникнуто юмором, эти образы ярко индивидуальны, нарисованы сочными бытовыми красками. Для описания Н. В. Гоголь использует иронию: «Риторы или солиднее... на лице всегда почти бывало какое-нибудь украшение в виде риторического тропа: или один глаз уходил под самый лоб, или вместо губы целый пузырь, или какая-нибудь другая примета...», "...он носил только оселедеи, и потому характер его в то время еще мало развился...» (Гоголь 1949, 147-151).

\section{5 Образ Вия}

До сих пор проблема генезиса гоголевского персонажа по имени Вий остаётся до конца не решённой. Эту задачу поставил перед литературоведами сам Н. В. Гоголь, написав в своей повести, что «Вий - есть колоссальное создание простонародного воображения. Таким именем называется у малороссиян начальник гномов, у которого веки на глазах идут до самой земли. Вся эта повесть есть народное предание. Я не хотел ни в чем изменить его и рассказываю почти в такой же простоте, как слышал». (Гоголь 1949, 147). С тех пор между исследователями ведутся дискуссии о том какой именно персонаж из украинской мифологии был прототипом данного литературного героя, так как полностью идентичный образ в мифологической системе украинского фольклора не был обнаружен (Левкиевская 1998, онлайн).

Образ Вия встречается в украинских легендах XVII века. Прототипом данного мифического персонажа был половецкий хан Боняк, прозванный русскими летописями «шелудивым хищником» за свои частые и кровавые набеги на Русь в 11 веке. Когда хан Боняк в 1097 году победил князя Святополка, его победа своей уничтожающей силой поразила современников, и распространились слухи, что там не обошлось без колдовства, чар и потусторонних сил. Это событие перешло в легенды, где образ хана приобрёл много ясных характеристик. В одной из вариантов главным из моментов в описании Боняка является 
ясновидение и парша: «Голова Боняка покрита гнійними струпами. А очі, сповнені чаклунською, руйнівною силою, прикриті величезними бровами /віями, що спускаються до самої землі» (Осавуленко, онлайн). Места записей этой легенды говорят о том, что эта легенда обычно встречается на Западной Украине, где иногда встречаются и названия поселков или церквей, связанные с этой легендой. Часто в записях этой легенды мало мифических деталей, так как летописцы считали эту легенду историческим событием и старались не упоминать в своих записях много сверхъестественных деталей. Самым древним письменным упоминанием об этой легенде является запись Ивана Томаса Юзефовича в хронике города Львов в 1634-1690 годах (Осавуленко, онлайн).

Существует несколько версий происхождения названия мистического персонажа по имени «Вий». Самая известная версия, что названия происходит от украинского слова «вія» (ресница), так как отличительной чертой Вия были именно длинные веки "до самой земли», которые по легенде приходилось подымать с посторонней помощью (чаще всего в легендах говорится, что веки подымали крестьяне или помощники Вия вилами). От этого и название чудовища «Вий».

По одной из версий название «Вий» происходит од украинского слова «віяти» (веять), так как Вий родился из страшного смерча, из адской стихии: «Косолапий і розкаряжений, обкиданий лишаями, оброслий мохом з розкуйовженим повним грязюки і гною волоссям Вій завжди весь у землі, бо там і живе - під землею. Чортячий страх породив страшне руйнівне чудовисько перед яким уся нечисть повзає та рачкує...Велет-песиголовець з одним оком посеред чола їсть людей...зловісний смерч пекельної стихі» (Войнович 2009, 293).

\section{6 Хома Брут}

Главный герой повести бурсак Киевской семинарии Хома Брут был сиротой. Он не знал ни отца своего, ни матери. Н. В. Гоголь изобразил его как человека весёлого, общительного и даже немного легкомысленного. Философ Хома Брут любил мирские удовольствия, женщин, весёлые компании, любил выпить и потанцевать. Как отмечает Н. В. Гоголь: «Философ был одним из числа тех людей, которых если накормят, то у них пробуждается необыкновенная филантропия.» $(1949,175)$. После первой ночи, проведённой у гроба панночки, пережив весь ужас ночного события, когда мёртвая ведьма, встав из гроба, летала ночью в церкви и старалась поймать его, Хома сумел вернуть себе (с помощью сна, еды и горилки) хорошее расположение духа.

К наукам в семинарии Хома относился безответственно, и часто заслуживал наказания. Учения ему давались трудно, так как он очень любил лежать и курить люльку, а если уж выпил, то любил непременно нанять музыкантов и отплясывал тропака. Несмотря на свою беззаботность, Хома был отважным человеком. Он сам не рвался в бой с нечистыми силами, но, когда по каким-то причинам из трёх семинаристов ведьма-панночка выбрала именно его, Хома сумел противостоять ей и даже сумел привести ведьму к гибели. На протяжении двух ночей он поседел, но всё-таки противостоял ведьме и, пришедшим ей на помощь, упырям и вурдалакам. Не выдержал Хома только взгляда в глаза Вия и погиб, связав так навсегда свою судьбу с судьбой единственной дочери местного сотника ведьмой-панночкой.

Образ Хомы Брута неоднозначен. Хома живет, ни о чём не задумываясь, однако встреча с потусторонним миром помогает ему найти в себе силы, нужные для борьбы со злом. Е. Васильева пишет, что Хому убивает «встреча с самим собой, с глубинами своего подсознания. Человек - целый мир, космос, непредсказуемый (как не знал Хома до встречи с мистическим о 
силах, таящихся в нем), порой ужасный. Тонкая грань (возможно, круг, который чертил Хома), отделяет нас от глубин подсознания, от мира, в который мы не вправе вступать». (2011, 14).

\section{7 Ведьма-панночка}

Панночка - дочь местного пана-сотника, красавица «...с роскошною косою, с длинными как стрелы ресницами» (Гоголь 1949, 156-157). Она нравилась местным парубкам и, по всей вероятности, очень понравилась Хоме Бруту, и даже после смерти, уже в гробу, она поражала Хому своей красотой: «Он подошел ко гробу, с робостию посмотрел в лицо умершей и не мог не зажмурить, несколько вздрогнувши, своих глаз. Такая страшная, сверкающая красота!» (Гоголь 1949, 173).

Для знакомства с Хомой панночка, будучи ведьмой, приняла облик старухи в «нагольном тулупе» (Гоголь 1949, 153). По рассказам местных жителей панночка принимала на себя и другие облики: в дом Шепчихи, например, она скреблась в виде собаки.

В том, что панночка была ведьмой у местных людей не было сомнения. О её жизни на хуторе читатель узнает в основном из рассказов хуторян, которые зачастую были основаны на слухах. Однако некоторые магические события, связанные с панночкой, происходят непосредственно в повести (например, катание панночки верхом на Хоме). Когда панночка умирает, её связь с силами зла становится очевидной. Перешагнув грань между жизнью и смертью, панночка уже не может видеть Хому: он спрятан от её мёртвых глаз в магическом круге (Софронова 2010, 108). Тем не менее панночка поднимается из гроба и отыскивает Хому, призывает на помощь упырей, вурдалаков, и наконец Вия.

\section{8 Краткий сравнительный анализ повести Н. В. Гоголя «Вий» с её экранизациями}

Таблица № 1: Фольклорные мотивы.

\begin{tabular}{|l|c|c|c|c|}
\hline & Повесть «Вий» & $\begin{array}{l}\text { Экранизация } \\
\text { 1967 года }\end{array}$ & $\begin{array}{l}\text { Экранизация } \\
\text { 2014 года }\end{array}$ & $\begin{array}{l}\text { Экранизация } \\
2018 \text { года }\end{array}$ \\
\hline $\begin{array}{l}\text { Сцена летания } \\
\text { Ведьмы верхом на } \\
\text { Хоме по небу }\end{array}$ & + & + & - & + \\
\hline $\begin{array}{l}\text { Магический круг, } \\
\text { нарисованный } \\
\text { мелом }\end{array}$ & + & + & + & + \\
\hline $\begin{array}{l}\text { Утренний крик } \\
\text { петуха, после } \\
\text { которого тёмные } \\
\text { силы утрачивают } \\
\text { свою мощь над } \\
\text { миром людей }\end{array}$ & + & + & & + \\
\hline $\begin{array}{l}\text { Сцена в церкви } \\
\text { Хома Брут читает } \\
\text { молитвы над }\end{array}$ & + & + & + & \\
\hline
\end{tabular}




\begin{tabular}{|l|l|l|l|l|}
\hline $\begin{array}{l}\text { гробом усопшей } \\
\text { Панночки) }\end{array}$ & & & \\
\hline
\end{tabular}

Сравнивая фольклорные мотивы, мы пришли к выводу, что авторы экранизаций не всегда придерживались фольклорной концепции, описанных в повести «Вий», однако фольклорная элементы присутствовали во всех, исследуемых нами, экранизациях. Так, например, в повести Н. В. Гоголя мистический персонаж по имени Вий обладал взглядом, неминуемо причиняющим смертельному человеку гибель. В отличии от фильма «Вий» 1967 года, где эта концепция была соблюдена, в последующих двух экранизациях этот тезис уже не соблюдался. В исследуемой нами повести персонаж по имени Вий - это воплощение зла, начальник подземных гномов, существо по своей природе чуждое человеческому роду, существо, вызывающее ужас даже у упырей и вурдалаков. Это концепция отражена и в картине «Вий» 1967 года. В одноименном фильме 2014 года персонаж Вий - это древний бог, вызывающий трепет и ужас даже у представителей загробного мира, однако здесь Вий - это зло, стоящее на страже справедливости. Посмотрев в глаза картографа Джонатана Грина, Вий не только не губит англичанина, но, исследуя своим взглядом сердце героя, выбирает его, как человека отличных моральных качеств. В экранизации 2018 года Вий - это древний демон, которого простому смертельному человеку очень трудно, но возможно победить, поэтому в конце фильма главному герою по имени Николай Васильевич Гоголь с помощью древнего заклинания и с огромным усилием удаётся уничтожить Вия.

Таблица № 2: Мистические мотивы.

\begin{tabular}{|c|c|c|c|c|}
\hline & Повесть «Вий» & $\begin{array}{l}\text { Экранизация } \\
1967 \text { года }\end{array}$ & $\begin{array}{l}\text { Экранизация } \\
2014 \text { года }\end{array}$ & $\begin{array}{l}\text { Экранизация } \\
2018 \text { года }\end{array}$ \\
\hline $\begin{array}{c}\text { Мистичес } \\
\text { кие мотивы }\end{array}$ & + & + & + & + \\
\hline
\end{tabular}

Сравнивая мистические представления в повести Н. В. Гоголя «Вий» с её последующими экранизациями, мы можем сказать, что во всех картинах была соблюдена вера простых людей в существования потусторонних миров и в взаимосвязь между этими мирами. Даже в экранизации 2014 года, которая лишена мистического начала, так как в этой картине добро и зло творят не мистические существа, а реальные люди, присутствует вера людей в потусторонние силы. Во всех картинах также была соблюдена концепция магии охранного круга, нарисованного мелом вокруг человека.

Таблица № 3: Соотношение юмора и ужасов.

\begin{tabular}{|c|c|c|c|c|}
\hline & Повесть «Вий» & $\begin{array}{l}\text { Экранизация } \\
1967 \text { года }\end{array}$ & $\begin{array}{l}\text { Экранизация } \\
2014 \text { года }\end{array}$ & $\begin{array}{l}\text { Экранизация } \\
2018 \text { года }\end{array}$ \\
\hline Юмор & + & + & + & - \\
\hline Ужасы & + & + & + & + \\
\hline
\end{tabular}


Сравнивая юмористические моменты, в повести «Вий» и её последующих экранизациях, мы можем сказать, что сатирических и весёлых моментов в каждой из последующих картин уменьшалось.

Авторы картины «Вий» 2014 года старались создать комедию в жанре фильма ужасов. С одной стороны, в данной картине много кадров, предназначенных вселять в сердца зрителей испуг и изумление. От этого фильм насыщен сценами, полными чудовищ всевозможных размеров, а также разными спецэффектами. С другой стороны, авторы старались развлекать зрителя, поэтому картина наполнена множеством разных, в той или иной мере, остроумных реплик и курьёзных моментов. Ужасающей эту картину делает трагичность судьбы панночки и Хомы Брута, а также мрачность жизни хуторян.

В отличие от фильма 2014 года, картина «Гоголь. Вий» 2018 года практически лишена юмора и курьезных, сатирических моментов. Она снята, скорее, в жанре детективного фильма ужасов. Детективным он является по той причине, что зритель до конца истории не знает, кто же убивает невинных девушек и по какой причине. В фильме много сцен, в которых показывается человеческая кровь или кровь животных. Юмористических моментов или сатирических реплик из повести Н. В. Гоголя в данной картине практически нет.

Таблица № 4: Образ Вия.

\begin{tabular}{|l|l|l|l|l|}
\hline & Повесть «Вий» & $\begin{array}{l}\text { Экранизация } \\
\text { 1967 года }\end{array}$ & $\begin{array}{l}\text { Экранизация } \\
\text { 2014 года }\end{array}$ & $\begin{array}{l}\text { Экранизация } \\
\text { 2018 года }\end{array}$ \\
\hline Имя & Вий & Вий & Вий & Вий \\
\hline Кто такой Вий & $\begin{array}{l}\text { Начальник } \\
\text { гномов }\end{array}$ & $\begin{array}{l}\text { Начальник } \\
\text { гномов }\end{array}$ & Древний бог & $\begin{array}{l}\text { Подземный } \\
\text { демон }\end{array}$ \\
\hline Сущность Вия & Воплощение зла & Воплощение зла & $\begin{array}{l}\text { Воплощение } \\
\text { зла, но он он } \\
\text { наделён } \\
\text { положительным } \\
\text { и чертами }\end{array}$ & Воплощение зла \\
\hline Судьба Вия & $\begin{array}{l}\text { Приводит Хому } \\
\text { Брута к гибели }\end{array}$ & $\begin{array}{l}\text { Приводит Хому } \\
\text { Брута к гибели }\end{array}$ & $\begin{array}{l}\text { Помогает } \\
\text { установить } \\
\text { справедливость }\end{array}$ & Погибает \\
\hline
\end{tabular}

Вий появляется во всех, описываемых в данной статье, экранизациях. Следует отметить, что в названиях картин отображена значимость данного персонажа. Авторы фильмов этим названием не только подчеркнули отношение картин к одноимённой повести Н. В. Гоголя, но также важность данного персонажа. В фильме 1967 года Вий изображён, как и в повести, огромным, приземистым косолапым человеком. Только веки у данного персонажа не опускались к самой земле, а только прикрывали глаза. В отличие от фильма 1967 года, в картине 2014 года у Вия веки уже опускаются основательно ниже ног демона, но в отличии от гоголевского персонажа, Вий 2014 года уже не приземистый и косолапый, а тонкий и дряблый, напоминающий не пришельца из под земли, а скорее пришельца из других миров. В фильме 2018 года авторы картины старались передать приземистость Вия, его тёмную природу, демона, порожденного под землёй. 
Что касается качеств Вия, его сущности, то в повести Н. В. Гоголя, как и в фильмах 1967 и 2018 годов, Вий - это воплощения зла. Демон, который одним взглядом способен убить простого смертного. Демон настолько могущественный, что способен преодолеть защитную силу магического круга. В картине 2018 года Вий не может преодолеть силу священного круга, удаётся ему это только благодаря отражению в зеркале, которое разрушает силу круга. В данной экранизации сила Вия не является непобедимой. Благодаря старинному заклинанию главному герою картины, встретившись с Вием взглядом, удаётся не только выжить, но и победить и уничтожить демона. В отличии от других картин и от повести Н. В. Гоголя, в фильме 2014 года Вий наделён некоторыми положительными качествами. И здесь он является демоном зла, но в данной картине (2018 года) Вий - это зло, стоящее на страже добра и справедливости.

Таблица № 5: Хома Брут.

\begin{tabular}{|l|l|l|l|l|}
\hline & Повесть «Вий» & $\begin{array}{l}\text { Экранизация } \\
\text { 1967 года }\end{array}$ & $\begin{array}{l}\text { Экранизация } \\
\text { 2014 года }\end{array}$ & $\begin{array}{l}\text { Экранизация } \\
\text { 2018 года }\end{array}$ \\
\hline $\begin{array}{l}\text { Является } \\
\text { главным героем }\end{array}$ & да & да & нет & нет \\
\hline $\begin{array}{l}\text { Бто такой Хома } \\
\text { Бурсак Киевской } \\
\text { семинарии }\end{array}$ & $\begin{array}{l}\text { Бурсак Киевской } \\
\text { семинарии }\end{array}$ & $\begin{array}{l}\text { Бурсак Киевской } \\
\text { семинарии }\end{array}$ & $\begin{array}{l}\text { Бывший бурсак } \\
\text { Киевской } \\
\text { семинарии } \\
\text { экзорцист }\end{array}$ \\
\hline $\begin{array}{l}\text { Хомадьма- Брут } \\
\text { панночка }\end{array}$ & $\begin{array}{l}\text { Является } \\
\text { причиной смерти } \\
\text { ведьмы- } \\
\text { панночки }\end{array}$ & $\begin{array}{l}\text { Является } \\
\text { причиной смерти } \\
\text { ведьмы- } \\
\text { панночки }\end{array}$ & $\begin{array}{l}\text { Невиновен } \\
\text { гибели панночки }\end{array}$ & $\begin{array}{l}\text { Является } \\
\text { причиной смерти } \\
\text { ведьмы Ульяны }\end{array}$ \\
\hline $\begin{array}{l}\text { Судьба Хомы } \\
\text { Брута }\end{array}$ & $\begin{array}{l}\text { В конце сюжета } \\
\text { погибает }\end{array}$ & $\begin{array}{l}\text { В конце сюжета } \\
\text { погибает }\end{array}$ & Остаётся в живых & $\begin{array}{l}\text { В конце сюжета } \\
\text { погибает }\end{array}$ \\
\hline
\end{tabular}

Сравнивая образ главного героя повести по имени Хома Брут с одноименными персонажами в исследуемых нами экранизациях, мы можем сказать, что образ этого героя менялся. Персонаж по имени Хома Брут присутствует во всех картинах, но не во всех экранизациях является главным героем. В отличии от картины с 1967 года (где Хома также, как и в повести, является главным персонажем), в дальнейших экранизациях создатели фильмов изменили эту концепцию. В фильме 2014 года в роли главного героя выступает английский картограф Джонатан Грин. А в картине с 2018 года главным героем является сам молодой Николай Васильевич Гоголь.

В каждой из последующих экранизаций Хома Брут утрачивает также свою весёлость и беззаботность. В фильме «Вий» 2014 года он также волей судьбы оказывается связан с панночкой, но, в отличии от сюжета повести и других экранизаций, в данном фильме Хома Брут выживает. В экранизации 2018 года Хома Брут появляется в Диканьке по собственной воле. Это уже не беззаботный семинарист, а экзорцист, который преследует ведьм и демонов и убивает ux. 
Таблица № 6: Ведьма-панночка.

\begin{tabular}{|c|c|c|c|c|}
\hline & Повесть «Вий» & $\begin{array}{l}\text { Экранизация } \\
1967 \text { года }\end{array}$ & $\begin{array}{l}\text { Экранизация } \\
2014 \text { года }\end{array}$ & $\begin{array}{l}\text { Экранизация } \\
2018 \text { года }\end{array}$ \\
\hline Панночка & $\begin{array}{l}\text { Является } \\
\text { ведьмой }\end{array}$ & $\begin{array}{l}\text { Является } \\
\text { ведьмой }\end{array}$ & $\begin{array}{l}\text { Не является } \\
\text { ведьмой }\end{array}$ & $\begin{array}{l}\text { Является } \\
\text { ведьмой }\end{array}$ \\
\hline $\begin{array}{l}\text { Ведьма- } \\
\text { панночка }\end{array}$ & $\begin{array}{l}\text { Дочь местного } \\
\text { сотника }\end{array}$ & $\begin{array}{l}\text { Дочь местного } \\
\text { сотника }\end{array}$ & $\begin{array}{l}\text { Дочь местного } \\
\text { сотника }\end{array}$ & $\begin{array}{l}\text { Приезжая вдова } \\
\text { Ульяна }\end{array}$ \\
\hline $\begin{array}{l}\text { Ведьма- } \\
\text { панночка и Хома } \\
\text { Брут }\end{array}$ & $\begin{array}{l}\text { Виновна } \\
\text { гибели } \\
\text { Брута }\end{array}$ & $\begin{array}{l}\text { Виновна } \\
\text { гибели } \\
\text { Брута }\end{array}$ & $\begin{array}{l}\text { Хома Брут - } \\
\text { избранный } \\
\text { судьбой (первый } \\
\text { встречный) }\end{array}$ & $\begin{array}{l}\text { Виновна } \\
\text { гибели } \\
\text { Брута }\end{array}$ \\
\hline $\begin{array}{l}\text { Судьба ведьмы- } \\
\text { панночки }\end{array}$ & $\begin{array}{l}\text { В данном } \\
\text { сюжете погибает }\end{array}$ & $\begin{array}{l}\text { В данном } \\
\text { сюжете погибает }\end{array}$ & $\begin{array}{l}\text { В данном } \\
\text { сюжете погибает }\end{array}$ & $\begin{array}{lr}\text { В данном } \\
\text { сюжете погибает }\end{array}$ \\
\hline
\end{tabular}

Сравнивая образ ведьмы-панночки в повести Н. В. Гоголя и последующих фильмовых адаптациях, мы можем сказать, что этот персонаж тоже интерпретировался по-разному. В повести автора, как и в картине 1967 года, ведьма-панночка появляется Хоме в образе старухи, и, оседлав семинариста, катается верхом на нём по ночному небу. Хоме удается с помощью молитв преодолеть силу её чар и опуститься с ней на землю. После чего Хома избивает панночку до полусмерти. Уже умерев, ведьма-панночка губит Хому, тем самым отомстив ему за свою смерть, и навеки соединив их судьбы. Здесь мы не видим у панночки ни раскаяния, ни сожаления о случившемся.

В отличии от этого, в фильме «Вий» 2014 года образ панночки-ведьмы не является таким однозначным. Здесь молодая девушка также является дочерью местного сотника. Она также трагически погибает в начале картины, но в её смерти не виновен Хома Брут. Здесь панночка не по собственной воле выбирает Хому, а по воле судьбы. Девушка ворожит на первого встречного, и сразу после этого на берегу пруда она встречает Хому. И здесь, в картине «Вий» 2014 года, о панночке говорят, что она ведьма, и что после смерти она летала в гробу, превращалась в старух, меняла свой человеческий образ, но у зрителя складывается впечатление, что это всё домыслы суеверных хуторян, а панночка - это молодая девушка, погибшая насильственной смертью.

В фильме «Гоголь. Вий» 2018 ведьма Ульяна уже не является дочерью сотника. Здесь эта героиня - молодая, красивая вдова, приехавшая в деревню год тому назад. В этой экранизации ведьма не ищет встречи с Хомой, а наоборот, сам Хома выискивает ведьму с целью убить её. После смерти ведьме удаётся погубить Хому Брута. Здесь ведьма выглядит ещё кровожаднее, она, не дожидаясь прихода Вия, силой вытаскивает Хому из прерванного на секунду магического круга, и впивается в его горло зубами. В этой картине у ведьмы также нет ни тени раскаяния или жалости над своей судьбой, или судьбой Хомы Брута.

\section{9 Заключение}

Анализируя вышесказанное, мы можем утверждать, что в экранизациях по мотивам повести Н. В. Гоголя «Вий» проявляется тенденция уклона интерпретации сюжета в сторону фильмов ужасов: каждая из последующих экранизаций повести в большей степени подчёркивает мистические элементы произведения.

Из трёх анализируемых нами картин самой привлекательной для современного зрителя может быть картина 2014 года. Несмотря на то, что в данном фильме был существенно изменён 
сюжет повести и есть много моментов, которые не вписываются в концепцию восточнославянского фольклора, в данной картине наряду с ужасами присутствует и юмор. В отличии от данного фильма 2014 года, экранизация «Вий» 1967 года была основана на буквальном подходе к первоисточнику, в ней режиссеры стремились к дословному переводу повести на язык другого искусства, поэтому эта картина является самой значительной с точки зрения передачи атмосферы произведения Н. В. Гоголя. Однако этот фильм не может конкурировать с более современным фильмам по качеству использованных в нём спецэффектов: современного зрителя трудно «напугать» фильмом-ужасом, снятым полвека тому назад. Что касается фильма «Гоголь Вий» 2018 г., то, по нашему мнению, он во многом уступает двум предыдущим картинам, так как в нём практически нет юмора. В данной картине присутствуют фольклорные элементы, но ужасы данного фильма зачастую касаются простых хуторян, а не мистических персонажей: в картине погибает не только Хома Брут и ведьма, но и восемь деревенских девушек. Маловероятно, что после просмотра данного фильма, современный зритель будет очарован его атмосферой и решит обратиться к оригинальному тексту повести.

\section{Использованная литература / References:}

\section{Печатные источники:}

БУКАРЁВА, А. Н. (2009): Юмор в повести Гоголя «Вий». In Сборник научных статей Нежин "Вий" Н.В.Гоголя: лингвостилистический аспект: Сборник научных статей. Нежин: Издательство НГУ им. Н. Гоголя, 2009. 99 с.

ВОЙнОВИЧ, В. (2009): Міри та легенди давньої України, Тернопіль, Навчальна книга. Богдан: 2009.392с. ISBN 966-629-555-9.

ГОГоль, Н. В. (1949): Миргород, Собрание сочинений. Москва: Государственное издательство художественной литературы, 1949. 350 с.

СОФРОНОВА, Л. А. (2010): Мифопоэтика раннего Гоголя. In Алетейя. Спб.: 2010. 296 с. ISBN 978-5-91419313-0.

\section{Онлайн-источники:}

ЛЕВКИЕВСКАЯ, Е. Е. (онлайн): К вопросу об одной мистификации или гоголевский «Вий» при свете украинской мифологии. In Studia mythologica slavica. Любляна: 1998. ISSN 1581-128X Режим доступа: http://sms.zrc-sazu.si/pdf/01/SMS_01_Levkievskaja.pdf [10. 02. 2020]

ОСАВУЛЕНКО, Е. (онлайн): Половецький монстр, або таємниця біографіі Вія. In Дослідження цивілізацій Сходу та Заходу. Збірник статmей. Киев. 2004. 143 с. Режим доступа: http://sinologist.com.ua/doslidzhennya-tsivilizatsij-shodu-ta-zah/ [03.05. 2019]

ВАСИЛЬЕВА, Е. (2011): К проблеме перевода русских антропонимов на чешский язык. In Opera Slavica: slavistické rozhledy. https://digilib.phil.muni.cz/bitstream/handle/11222.digilib/117380/2_OperaSlavica_21-2011-

3_3.pdf?sequence=1 [14.09. 2020]

ТИШКОВ, В. А., СИТянСКИЙ, Г. Ю., редкол. (онлайн): Народы и религии мира. In Большая Российская энциклопедия. Москва: $1998 . \quad$ Режим доступа: https://peoples_religion.academic.ru/771/\%D0\%B1\%D1\%8B\%D0\%BB\%D0\%B8\%D1\%87\%D0\%BA\%D0\%B0 [12. 02. 2020]

ТУРОВЕЦ, В. А. (онлайн): Фольклорные и религиозно-мистические мотивы в повести Н. В. Гоголя «Вий». In Вісник студентського наукового товариства ДоннУ імені Василя Стуса. Вінниця. 2013. Режим доступа: http://jvestnik-sss.donnu.edu.ua/article/view/1232/1259 [03.0 6. 2019] 


\section{Профиль автора:}

Галина Марешева, магистр, преподаватель русского языка

Научные интересы: русская литература, поэзия

e-mail: 447555@mail.muni.cz

Место работы: Základní škola a Mateřská škola Tatenice, Tatenice 149, okr. Ústí nad Orlicí, 56131.

\section{Author's profile:}

Halyna Mareshova Mgr. a teacher of Russian language

Research interests: Russian literature, poetry

e-mail:447555@mail.muni.cz

Place of work: Základní škola a Mateřská škola Tatenice, Tatenice 149, okr. Ústí nad Orlicí, 56131.

\section{Профиль автора:}

Татьяна Савченко, магистр, преподаватель русского языка

Научные интересы: дидактика иностранных языков, детская литература, поэзия, коммуникативная компетенция

e-mail: savchenko@ped.muni.cz

Место работы: Кафедра русского языка и литературы, Педагогический факультет, Университет им. Масарика, Poříčí 7/9, Brno, 60300.

\section{Author's profile:}

Tatiana Savchenko, Mgr. et Mgr., a teacher of Russian language

Research interests: didactics of foreign languages, children's literature, poetry, communicative competence e-mail: savchenko@ped.muni.cz

Place of work: Department of Russian language and literature, Faculty of Education, Masaryk University, Pořičí 7/9, Brno, 60300. 